\title{
Purification and characterization of a galactose- specific lectin from the eggs of coho salmon Oncorhynchus kisutch and its interaction with bacterial fish pathogens
}

\author{
A. N. Yousif ${ }^{1}$, L. J. Albright ${ }^{1}$, T. P. T. Evelyn ${ }^{2}$ \\ ${ }^{1}$ Institute for Aquaculture Research, Department of Biological Sciences, Simon Fraser University, Burnaby, British Columbia, \\ Canada V5A 1 S6 \\ ${ }^{2}$ Department of Fisheries and Oceans, Pacific Biological Station, Nanaimo, British Columbia, Canada V9R 5K6
}

\begin{abstract}
The yolk of coho salmon Oncorhynchus kisutch eggs contains a lectin which proved capable of binding to Aeromonas salmonicida cells, but showed no such activity with other fish pathogens such as A. hydrophila, Vibrio anguillarum, V. ordalii, or Renibacterium salmoninarum. The interaction between the lectin and $A$. salmonicida was demonstrated by a test in which the protein was adsorbed onto bacterial cells. Boiling the bacterial cells for $1 \mathrm{~h}$ did not alter their ability to adsorb the lectin. The lectin was purified by affinity chromatography on D-galactose-Sepharose 4B, and was shown by SDSPAGE to be a $24.5 \mathrm{kDa}$ protein; it was heat stable and its binding property was inhibited by D-galactose, D-galactosamine, and L-rhamnose. The amino acid composition and N-terminal amino acid sequence of the purified lectin were also determined. The amino acid sequence was in places reminiscent of the sequences found in recognition molecules such as antibodies and certain cell receptor sites.
\end{abstract}

KEY WORDS: Lectin · Salmonids · Eggs · Pathogens

\section{INTRODUCTION}

Lectins or agglutinins are proteins or glycoproteins which agglutinate erythrocytes or other types of cells by combining with a carbohydrate moiety of cell membranes. They were first discovered in plants, but recently they have also been found in various tissues and organs of both vertebrates and invertebrates (Sharon \& Lis 1989).

Although the presence of lectins has been recorded in the ova of many species of the family Salmonidae, only a few of these lectins have been purified and investigated to any extent (Uhlenbuck \& Prokop 1967. Anstee et al. 1973, Voak et al. 1974, Krajhanzl et al. 1978, Ozaki et al. 1983, Kamiya et al. 1990). The function of these lectins is not yet known. However, in lower vertebrates, which lack a highly developed immune system, they are thought to serve antibodylike functions in defense against foreign entities, including bacteria (Prokop et al. 1968, Voss et al. 1978, Kudo \& Inoue 1986, 1989).

Studies reported in this paper were part of a project aimed at investigating the role of naturally occurring non-specific defense factors such as lectins in the eggs of coho salmon Oncorhynchus kisutch. The lectin was purified and its physicochemical properties were partially characterized. The interaction of the lectin with bacterial fish pathogens is also discussed.

\section{MATERIALS AND METHODS}

Eggs and preparation of yolk extract. Unfertilized, non-water-hardened eggs were obtained from gravid 
females of coho salmon that had returned from the sea to spawn in the Capilano River near Vancouver, British Columbia (B.C.), Canada. The eggs were transported on ice to the laboratory and immediately stored at $-20^{\circ} \mathrm{C}$. Prior to use, the eggs were thawed at room temperature and processed as follows. Approximately $40 \mathrm{ml}$ of eggs were washed with 3 changes of phosphate-buffered saline (PBS, $\mathrm{pH} 7.1$ ) to remove as much of the ovarian fluid as possible. The eggs were then homogenized in a tissue grinder at room temperature, and the homogenate filtered through cotton cheesecloth. To $25 \mathrm{ml}$ of the filtrate (yolk), $75 \mathrm{ml}$ of precooled $\left(-20^{\circ} \mathrm{C}\right)$ isopropyl alcohol was added with mixing at $4^{\circ} \mathrm{C}$ for 20 to $30 \mathrm{~min}$. The precipitate was allowed to settle for $5 \mathrm{~min}$ before the supernatant was decanted. For complete removal of lipids, this procedure was repeated 3 times with the alcohol and twice with precooled acetone. The final residue was collected in a Buchner funnel (filter paper no. 1, Whatman Intl, Ltd, Maidstone, UK), washed with a small amount of acetone, and air dried. The dry powder was extracted with $75 \mathrm{ml}$ of PBS with stirring for $1 \mathrm{~h}$ at room temperature. The supernatant (yolk extract, YE) was collected following centrifugation $(12000 \times g)$ and stored at $4{ }^{\circ} \mathrm{C}$.

Bacterial strains. The bacterial strains were isolated from the following sources: Aeromonas salmonicida (strain \#76-30, the causative agent of furunculosis) and Renibacterium salmoninarum (strain \#384) were isolated from juvenile salmon at the Department of Fisheries and Oceans (DFO) Quinsam River Hatchery, Vancouver Island, B.C. in 1976 and 1979, respectively. A. hydrophila (strain \#35, known to cause a hemorrhagic septicemia in salmonids) was isolated from an adult pink salmon Oncorhynchus gorbuscha at the Robertson Creek Hatchery, B.C. in 1965. Vibrio ordalii (strain \#74-48) was isolated from sockeye salmon $O$. nerka with vibriosis at the Pacific Biological Station, Nanaimo, B.C. V. anguillarum (strain \#R20) was isolated from chinook salmon $O$. tshawytscha with vibriosis in 1989 at Read Island, B.C. Stock cultures of all bacteria were kept at $-70^{\circ} \mathrm{C}$ in tryptic soy broth (TSB, Difco, Detroit, MI, USA) with or without salt, or in KDM-2 broth (Evelyn 1977). Both media were supplemented with $1 \%$ gelatin. Propagation of all bacteria except R. salmoninarum was carried out using brain heart infusion (BHI, Difco) agar, with or without salt at $15^{\circ} \mathrm{C}$. R. salmoninarum was grown on charcoal agar medium (Daly \& Stevenson 1985) that had been made selective (SKDM-C) for the bacterium by the addition of antibiotics described by Austin et al. (1983).

Treatment of the bacteria. Bacterial cultures were aseptically scraped of agar plates, suspended and washed twice in sterile PBS by centrifugation $(6000 \times g$ for $15 \mathrm{~min}$ at $4{ }^{\circ} \mathrm{C}$ ), and the final suspension was adjusted to an absorbance of 5.0 at $540 \mathrm{~nm}$ before being heated at $100^{\circ} \mathrm{C}$ for $1 \mathrm{~h}$. The bacterial cells were then washed 3 more times in PBS and the suspensions were finally stored at $4^{\circ} \mathrm{C}$.

Adsorption test. Adsorption of coho egg lectin onto bacterial cells was examined by incubating bacterial cells (cell pellets from $100 \mu \mathrm{l}$ of bacterial suspension of each species or a combination of all species) with $100 \mu \mathrm{l}$ of YE (total protein $=650 \mu \mathrm{g}$ ) for $14 \mathrm{~h}$ at $4{ }^{\circ} \mathrm{C}$ with occasional shaking. Following centrifugation, the supernatants were removed and examined for the presence of lectin using gradient sodium dodecyl sulfate-polyacrylamide gel electrophoresis (SDS-PAGE). Bacterial pellets were then washed in PBS $(1.5 \mathrm{ml})$, and bound lectin was eluted by resuspending the pellet in $100 \mu \mathrm{l}$ of $0.2 \mathrm{M} \mathrm{D}$-galactose or L-rhamnose for $2 \mathrm{~h}$ at room temperature followed by centrifugation. The supernatants were dialysed extensively (2 d) against distilled water and kept at $4^{\circ} \mathrm{C}$.

Effect of saccharides, 2-mercaptoethanol, and heat. The inhibitory effects of saccharides and 2-mercaptoethanol on the binding of the lectin to heat-killed Aeromonas salmonicida (strain \#76-30 $\mathrm{A}^{+}$) cells were studied as follows. To $100 \mu \mathrm{l}$ of one of the test solutions I(TS) = L-rhamnose, D-galactose, D-mannose, D-glucose, $\mathrm{N}$-acetyl D-galactosamine, D-mannosamine, Dgalactosamine or 2-mercaptoethanol, each at $0.2 \mathrm{M}$; Sigma, St. Louis, MO, USA] $100 \mu \mathrm{l}$ of YE was added. The mixtures were incubated for $2 \mathrm{~h}$ at room temperature. Each bacterial suspension $(100 \mu l)$ was centrifuged for $10 \mathrm{~min}$ at room temperature and the supernatant was discarded. The pellet was then resuspended in the YE-TS mixture and the suspension incubated for $14 \mathrm{~h}$ at $4^{\circ} \mathrm{C}$. Finally, the supernatant was collected by centrifugation and examined for the presence of lectin using gradient SDS-PAGE. The effect of heat on the lectin's ability to bind to the surface of $A$. salmonicida was examined by incubation of YE at $100^{\circ} \mathrm{C}$ for $15 \mathrm{~min}$. Following heating and centrifugation, the residual adsorption activity of the lectin in the supernatant was tested as outlined before.

SDS-PAGE. Electrophoresis procedures for SDS $4.5 \%$ stacking and linear gradient $(5-20 \%, 10-20 \%)$ separating acrylamide gels with 2-mercaptoethanol, and silver staining were identical with those outlined in Johnston \& Thorpe (1987). The samples were run at a constant current of $25 \mathrm{~mA} \mathrm{gel}^{-1}(140 \times 125 \times 1.5 \mathrm{~mm})$ using a large vertical slab gel electrophoresis unit (Se 600, Hoeffer Scientific Instruments, San Francisco, CA, USA)

Low molecular weight protein standards (BIO-RAD, Richmond, VA, USA) were included in each run. All chemicals used in electrophoresis were purchased from Sigma.

Western blotting. Preparation of rabbit antiserum: Antiserum against coho egg lectin was produced by 
injection of a New Zealand white female rabbit with the purified lectin mixed with AdjuPrime immune modulator (Pierce, Rockford, IL, USA). AdjuPrime was ground in a mortar and pestle and suspended in the antigen solution to a final concentration of $3.3 \mathrm{mg} \mathrm{ml}^{-1}$ Approximately $112 \mu \mathrm{g}$ of lectin was injected subcutaneously and the rabbit was allowed to rest for $2 \mathrm{wk}$ after which it was boosted with $98 \mu \mathrm{g}$ of the antigen. Blood was collected from the marginal ear vein, allowed to clot at $37^{\circ} \mathrm{C}$ for $1 \mathrm{~h}$ and then incubated overnight at $4^{\circ} \mathrm{C}$. The serum was collected by centrifugation and kept at $-20^{\circ} \mathrm{C}$. Normal rabbit serum was collected before immunization for use as a negative control.

Blotting technique: Discontinuous SDS-PAGE of samples was performed as described above. Prestained markers of low molecular mass (BIO-RAD) were included with each gel. Polypeptides were then transferred electrophoretically onto $0.45 \mu \mathrm{m}$ nitrocellulose (N/C) membrane (BIO-RAD), using a semi-dry transblot apparatus (2117-250 Novablot LKB, Bromma, Sweden) at $0.8 \mathrm{~mA} \mathrm{~cm}^{-2}$ for $2 \mathrm{~h}$. All subsequent manipulations were performed at room temperature. The N/C membranes were washed briefly in Tris-buffered saline (TBS: $20 \mathrm{mM}$ Tris, $500 \mathrm{mM} \mathrm{NaCl}, \mathrm{pH}$ 7.5) and then blocked for $1 \mathrm{~h}$ with $3 \%$ solution (w/v) of gelatin in TBS. The $\mathrm{N} / \mathrm{C}$ membranes were then washed twice in a $0.05 \%$ solution of Tween-20-containing TBS (TTBS) and exposed to a solution of rabbit anti-coho egg lectin (diluted 1:50 in 1\% gelatin-TTBS = antibody buffer) overnight with gentle shaking. The N/C membranes were washed twice in TTBS and then exposed to a solution of horseradish peroxidase (HRP) conjugated to goat anti-rabbit IgG (BIO-RAD), diluted 1:1500 in antibody buffer for $1 \mathrm{~h}$ with gentle shaking. The solution was then discarded and the N/C membranes were washed twice in TTBS and once in TBS. The N/C membranes were developed by addition of the HRP substrate (4-chloro-1-naphthol, BIO-RAD). Developed blots were kept in the dark until photographed.

Purification of egg lectin. Production of galactose affinity medium: Damp Sepharose 4B (10 g, Sigma) was washed with $500 \mathrm{ml}$ of distilled water and dried to dampness by suction on a glass-fretted funnel. The Sepharose was then resuspended in a solution containing $10 \mathrm{ml}$ butanedioldiglycidyl ether and $10 \mathrm{ml} 0.6 \mathrm{~N}$ $\mathrm{NaOH}$ containing $0.6 \% \mathrm{NaBH}_{4}$. The gel was left to react overnight on a horizontal shaker at room temperature and then washed with 1.51 of distilled water as before. Coupling with carbohydrate was achieved by resuspending the epoxy-activated Sepharose in a $50 \mathrm{ml}$ solution of $1.5 \mathrm{M} \mathrm{D}$-galactose in $0.5 \mathrm{M} \mathrm{Na}_{2} \mathrm{HCO}_{3}$ at $\mathrm{pH}$ 11. The mixture was kept in suspension overnight on a horizontal shaker held at $50^{\circ} \mathrm{C}$. This was followed by washing the gel with $1.5 \mathrm{l}$ of distilled water as before. The gel was then resuspended in $50 \mathrm{ml}$ of $0.5 \mathrm{M}$ ethanolamine for $1 \mathrm{~h}$ with shaking at room temperature. This was necessary to block any of the remaining activated epoxy groups. The gel was washed with distilled water as before and the slurry was equilibrated in PBS, and packed into a $10 \mathrm{~cm}$ long column (internal diameter $=1.6 \mathrm{~cm}$ ).

Chromatography procedure: Coho egg lectin was purified from yolk materials by affinity chromatography using a column $(1.6 \times 5.2 \mathrm{~cm})$ of galactose substituted epoxy-activated Sepharose 4B. A volume of 10 $\mathrm{ml}$ of YE (total protein $=90 \mathrm{mg}$ ) was applied onto the column at a flow rate of $15 \mathrm{ml} \mathrm{h}^{-1}$. This procedure was repeated 3 times with the eluate, and then the column was washed with PBS until the absorbance of the eluate at $280 \mathrm{~nm}$ was zero. Bound protein was eluted with $0.2 \mathrm{M} \mathrm{D}$-galactose in PBS and fractions of $2 \mathrm{ml}$ were collected. The eluted protein fractions were pooled. dialysed extensively $(2 \mathrm{~d})$ against distilled water at $4{ }^{\circ} \mathrm{C}$, and lyophilized.

The purity and molecular weight of the purified lectin were determined electrophoretically using SDSPAGE

Protein quantification. Protein concentration was determined according to the method of Bradford (1976), using bovine serum albumin as a standard.

Amino acid analyses. N-terminal sequence was determined by using an Applied Biosystems model 470A gas-phase sequencer with on-line phenylthiohydantoin analysis. The $\mathrm{N}$-terminal amino acid sequence was confirmed using the major $24.5 \mathrm{kDa}$ protein band that had been separated by SDS-PAGE and electrophoretically transferred to Immobilon (Millipore Corp., Bedford, MA, USA). The Immobilon-bound protein was stained with silver, cut from the membrane, and sequenced directly (LeGendre \& Matsudaira 1988). Comparisons of the $\mathrm{N}$-terminal sequence of the purified lectin with proteins listed in the GenBank database (release number 64), SWISS-PROT (release number 14), and GENPEPT (release number 63) were made using the BLAST computer program (daily updated synthesis of all world available protein sequence data bases)

Total amino acid analysis of the purified protein was obtained on samples hydrolyzed in gaseous $\mathrm{HCl}$ $\left(165^{\circ} \mathrm{C}, 1 \mathrm{~h}\right)$ and analyzed using an Applied Biosystems model 420 amino acid derivatizer analyzer. Derivatized proteins were removed from the reaction mixture by overnight incubation $\left(4^{\circ} \mathrm{C}\right.$, dark) in the presence of small pieces of Immobilon. The nylonmembrane-bound proteins were removed from the mixture, rinsed, air-dried, and stored at $-20^{\circ} \mathrm{C}$ until analysis. $\beta$-Lactoglobulin was used as a standard to confirm the success of the carboxymethylation reaction. 


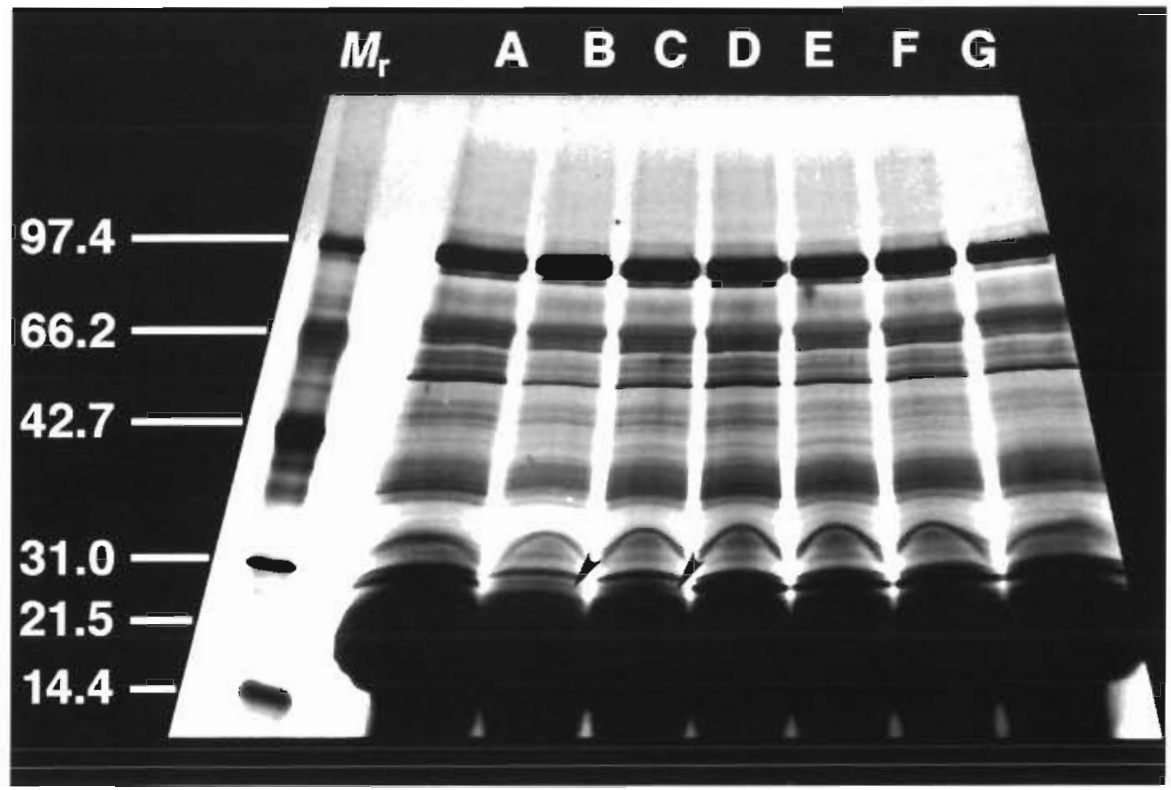

Fig. 1 Oncorhynchus kisutch. Electrophoretic patterns of the yolk extract used in the adsorption test. ( $\lambda$ Unadsorbed; or adsorbed with: (B) a combination of $C$ to $G_{i}$ (C) Aeromonas salmonicida; (D) A. hydrophila; (E) Vibrio ordalii; (F) V. anguillarum; (G) Renibacterlum salmoninarum. $M_{\mathrm{r}}$ : BIO-RAD low molecular weight standards. Reduced (2-mercaptoethanol) samples were sun on a $5-20 \%$ gradient SDSpolyacrylamide gel, and silver stained. Arrows show lack of lectin indicating its adsorption to the added bacterial cells

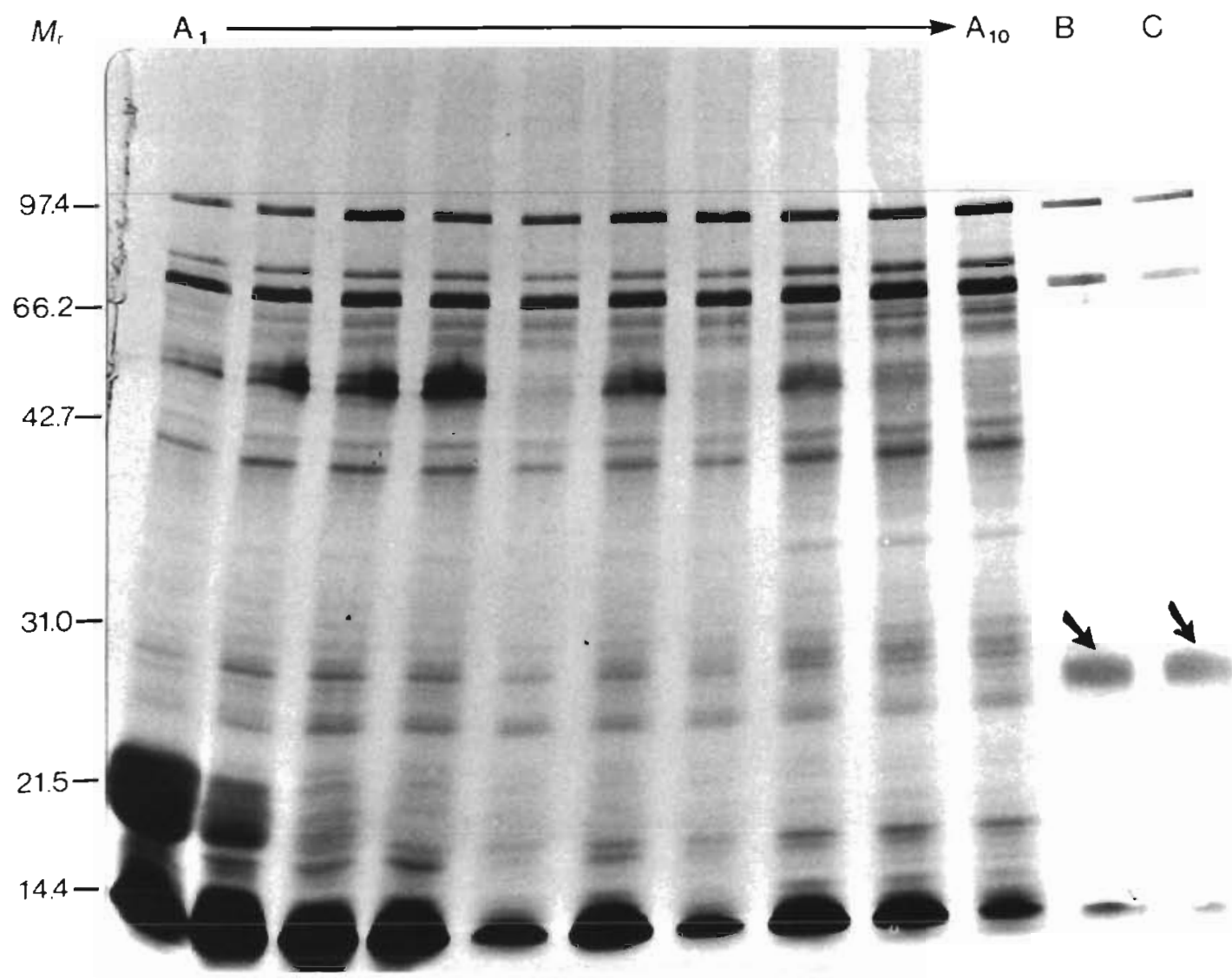

Fig. 2. Oncorhynchus kisutch. Phosphate-buffered saline (PBS) washes $\left(A_{1}\right.$ to $\left.A_{10}\right)$ of Aeromonas salmoncida cells following incubatıon with the yolk extract of coho salmon eggs. Lectin (arrows) was eluted by (B) D-galactose or (C) L-rhamnose. $M_{r}$ : BIO-RAD low molecular weight standards Reduced (2-mercaptoethanol) samples were run on a $10-20 \%$ gradient SDS-polyacrylamide gel, and silver stained 


\section{RESULTS}

Preliminary SDS-PAGE runs of YE revealed the presence of a large number of egg yolk proteins capable of entering a gel of $\geq 10 \%$ acrylamide. However, standard ( $12.5 \%$ acrylamide) gels did not produce satisfactory separations because of their limited porosity. In this study, linear gradient polyacrylamide gels were therefore used. The latter proved efficient, in the range used, for separating egg proteins into discrete bands corresponding to individual proteins and their subunits. An electrophoretic profile of the YE of coho salmon eggs is shown in Fig. 1, lane A. The profile consisted of a considerable number of PBS-soluble proteins and glycoproteins, most of which had a molecular weight $\left(M_{\mathrm{r}}\right)$ within the range of the protein standards $(97.4$ to $14.5 \mathrm{kDa})$.

Of all bacteria tested, only Aeromonas salmonicida cells exhibited substantial ability to absorb a single protein molecule from the YE (Fig. 1, lane C). This ability to adsorb the lectin seemed not to be affected by the presence, in the reaction mixture, of bacterial cells other than $A$. salmonicida (Fig. 1). The resulting linkage between bacterial cells and the lectin that took place dur- ing the adsorption was strong enough to allow rigorous washing, with PBS, that removed most of the unbound egg proteins (Fig. 2, lanes $A_{1}$ to $A_{10}$ ). This was followed by addition of D-galactose or L-rhamnose that eluted the lectin from the surface of the bacterial cells in a semipurified form (Fig 2, lanes B to $C$ ). The upper protein bands $\left(M_{\mathrm{r}}=97\right.$ and $\left.66 \mathrm{kDa}\right)$ that occurred in sugar eluates were considered contamination by egg proteins because PBS washes contained these proteins.

To characterize the binding specificity of the lectin, various sugars were tested for their ability to inhibit lectin binding in the adsorption test. Fig. 3 depicts the effect of sugars and denaturing agents on the lectin. Addition of simple sugars (D-galactose, D-galactosamine or L-rhamnose) to the YE before the latter was incubated with cells of Aeromonas salmonicida resulted in total inhibition of the lectin and prevented any adsorption of the molecule to bacterial cells. On the other hand, D-mannose, D-glucose, N-acetyl Dgalactosamine, D-mannosamine or 2-mercaptoethanol had no inhibitory effect on the binding property of the lectin. Furthermore, heating the YE at $100^{\circ} \mathrm{C}$ for 15 min did not precipitate the lectin out of solution or inhibit its binding activity (Fig. 4).

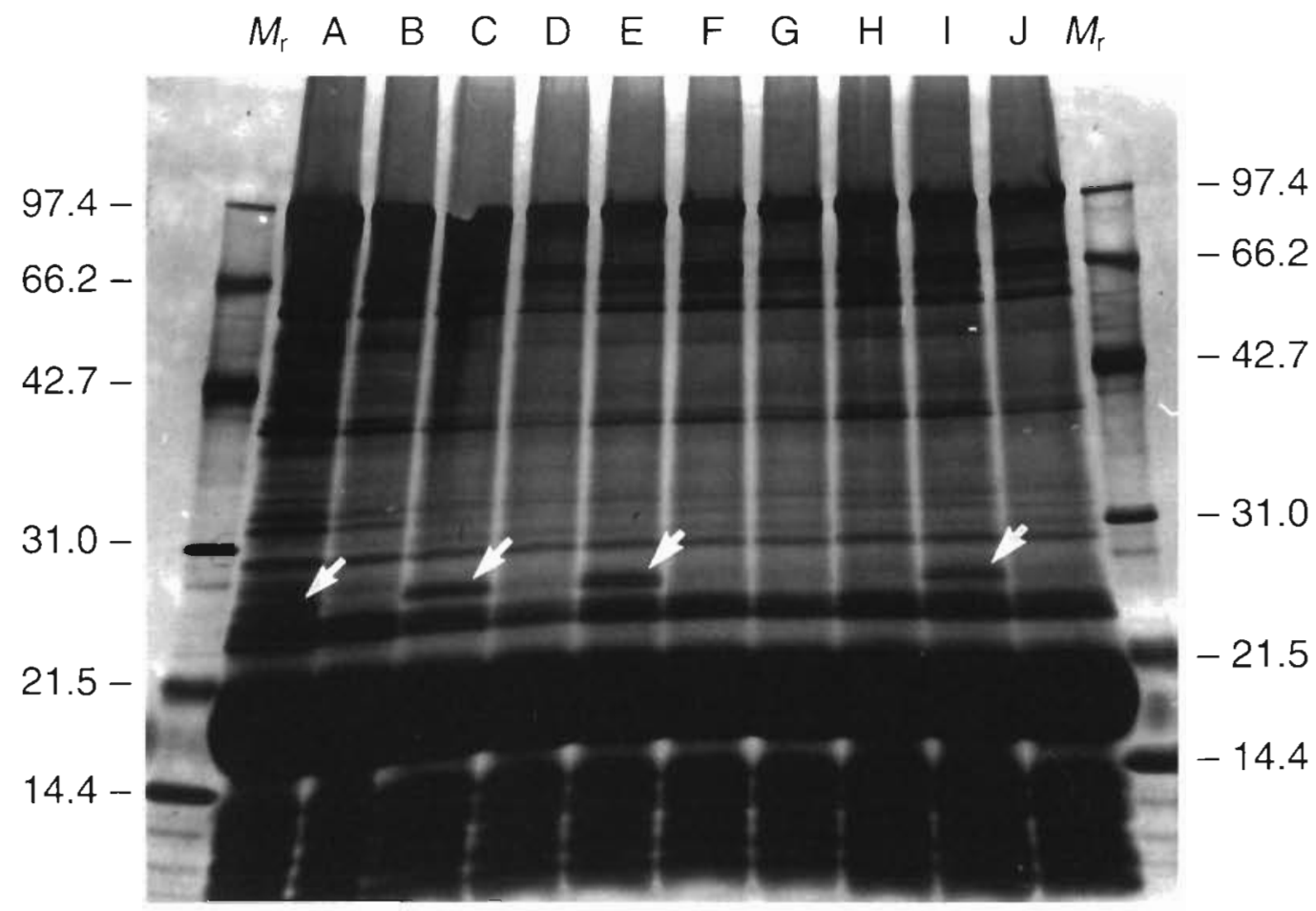

Fig. 3. Oncorhynchus kisutch. Electrophoretic patterns of (A) coho salmon egg yolk extract (YE); YE interaction with A. salmonicida in the (B) absence and $(C)$ presence of L-rhamnose, (D) the presence of D-mannose, (E) the presence of $D$-galactose, (F) presence of D-glucose, (G) the presence of $\mathrm{N}$-acetyl D-galactosamine, (H) the presence of D-mannosamine, (l) the presence of D-galactosamine, and $(\mathrm{J})$ the presence of 2 -mercaptoethanol. $M_{r}$ : BIO-RAD low molecular weight standards. Reduced (2-mercaptoethanol) samples were run on a 10-20\% gradient SDS-polyacrylamide gel, and silver stained. Arrows indicate unadsorbed lectin 
$\begin{array}{llll}\text { M } & \text { B } & \text { C }\end{array}$

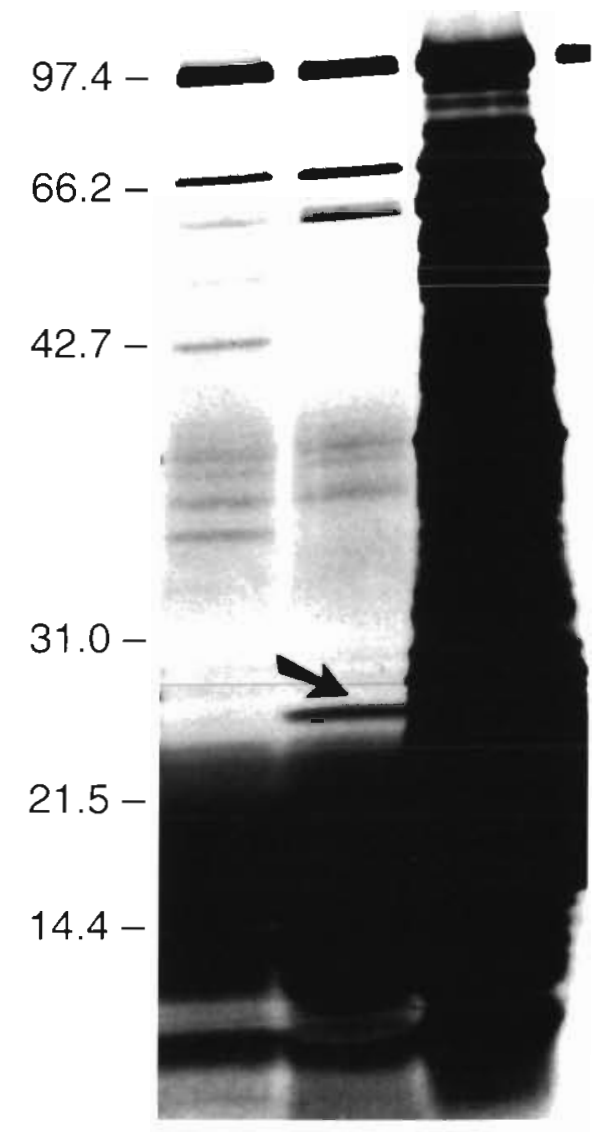

Fig. 4. Oncorhynchus kisutch. Effect of heat on the yolk extract (YE) and lectin of coho salmon eggs. YE was incubated at $100^{\circ} \mathrm{C}$ for $15 \mathrm{~min}$ and centrifuged. The resultant supernatant was then used in the adsorption test with Aeromonas salmonicida. (A) adsorbed, (B) unadsorbed lectin (arrow), (C) Y.E. $M_{\mathrm{r}}$ : BIO-RAD low molecular weight standards. Reduced (2-mercaptoethanol) samples were run on a 5-20\% gradient SDS-polyacrylamide gel, and silver stained

The procedure used for the simultaneous precipitation of coho egg proteins and the lectin, and for extracting the egg lipids, was also found to be efficient for the purification of other materials such as immunoglobulins from chicken eggs (Bade \& Stegemann 1984). The use of organic solvents such as iso- propyl alcohol and acetone to precipitate the egg lectin had no effect on its binding activity, and the lectin was readily redissolved in PBS together with other egg proteins.

The lectin was purified from coho eggs by affinity chromatography (Fig. 5). Following adsorption of the lectin onto the D-galactose-Sepharose $4 \mathrm{~B}$ column, proteins other than lectin were washed off the column with PBS, and the lectin was then eluted with the competitive sugar (D-galactose) in a single peak (65 $\mu$ g total protein). The eluted lectin constituted $0.1 \%$ of the total protein loaded onto the column. SDS-PAGE (with 2-mercaptoethanol) of the peak fractions revealed 1 major band $\left(M_{\mathrm{r}}=24.5 \mathrm{kDa}\right)$ and 3 additional faint bands $\left(\sim M_{\mathrm{r}}=\right.$ $23,18,14.4 \mathrm{kDa})$. Noteworthy, however, was a fourth faint band $\left(\sim M_{\mathrm{r}}=42.7 \mathrm{kDa}\right)$, visible when the loading density of lectin was increased (Fig. 6A, lane 2).

The isolated lectin was tested for purity by Western blot. A single band was obtained that corresponded to the major lectin band $\left(M_{\mathrm{r}}=24.5 \mathrm{kDa}\right)$ in the purified sample (Fig. $6 \mathrm{~B}$ ). The band $M_{\mathrm{r}}=18 \mathrm{kDa}$, that happened to occur in trace quantities in the purified material, was considered to represent contamination by a major antigenic protein present in coho eggs. The other faint bands were probably degradation fragments of the $24.5 \mathrm{kDa} M_{\mathrm{r}}$ protein.

The 45 amino acid $\mathrm{N}$-terminal sequence of the purified lectin was determined and is indicated in Table 1. The BLAST N-terminal sequence comparison between the $24.5 \mathrm{kDa}$ lectin and protein sequences listed in the data bases did not reveal any other protein with a sequence similar to that of the lectin. However, there

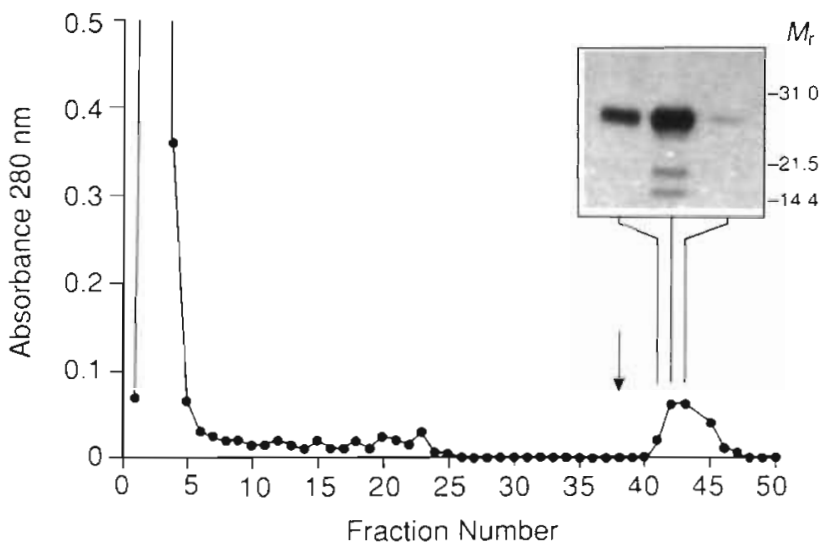

Fig. 5. Oncorhynchus kisutch. Affinity chromatography of coho salmon egg lectin on D-galactose-Sepharose $4 \mathrm{~B}$ column $(1.6 \times 5.2 \mathrm{~cm})$. A volume of $10 \mathrm{ml}$ of yolk extract containing approximately $90 \mathrm{mg}$ of protein was applied to the column. After washing the column with PBS, the lectin was eluted with $0.2 \mathrm{M} \mathrm{D}$-galactose in the buffer (arrow). Fractions of $2 \mathrm{ml}$ were analyzed for UV absorbance $(\bullet)$ ), and for proteins using SDS-PAGE (inset) 
Fig. 6. Oncorhynchus kisutch. (A) SDSPAGE and (B) Western blot of reduced (2-mercaptoethanol) samples of coho salmon egg yolk extract (lane 1), and purified lectin from galactose affinity chromatography (lane 2). After electrophoresis, protein gels were stained with silver, and nitrocellulose membranes were processed as described in the 'Materials and methods' The primary antibody was rabbit immune serum raised against lectin. The secondary antibody was goat anti-rabbit IgG conjugated to horseradish peroxidase. $M_{\mathrm{r}}$ standards are indicated ( $\left.\mathrm{kDa}\right)$

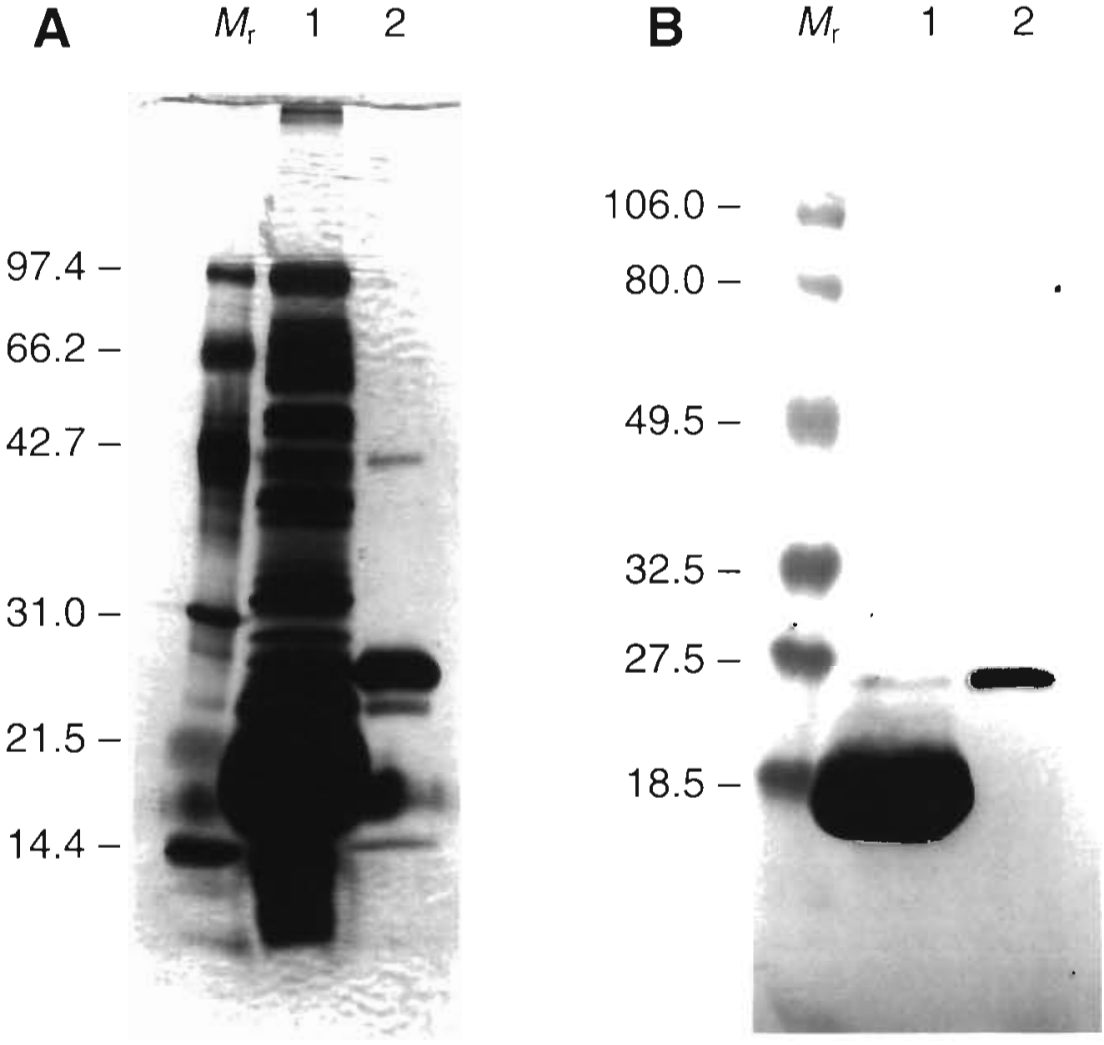

Table 1 Oncorhynchus kisutch. N-terminal sequence of coho salmon egg lectin. Determinations were made using the major $(24.5 \mathrm{kDa})$ subunit of the purified protein

\begin{tabular}{|ccccccccccc}
\hline Cycle & $\begin{array}{c}\text { Identified } \\
\text { residue }\end{array}$ & Cycle & $\begin{array}{c}\text { Identified } \\
\text { residue }\end{array}$ & Cycle & $\begin{array}{c}\text { Identified } \\
\text { residue }\end{array}$ & $\begin{array}{c}\text { Cycle } \\
\text { Identified } \\
\text { residue }\end{array}$ & $\begin{array}{c}\text { Cycle } \\
\text { Identified } \\
\text { residue }\end{array}$ \\
\hline 1 & Ala & 10 & Asp & 19 & Lys & 28 & Gly & 37 & Ile \\
2 & Ile & 11 & Ala & 20 & Ile & 29 & Arg & 38 & Gly \\
3 & Ser & 12 & Leu & 21 & His & 30 & Cys & 39 & Cys \\
4 & Ile & 13 & Leu & 22 & Ile & 31 & Gln & 40 & Pro \\
5 & Thr & 14 & Gln & 23 & Lys & 32 & His & 41 & Asp \\
6 & Cys & 15 & Cys & 24 & Arg & 33 & Asp & 42 & Asn \\
7 & Glu & 16 & Asp & 25 & Ala & 34 & Val & 43 & Gln \\
8 & Gly & 17 & Gly & 26 & Asn & 35 & Cys & 44 & Leu \\
9 & Ser & 18 & Gly & 27 & Tyr & 36 & Ser & 45 & Thr \\
\hline
\end{tabular}

were weak homologies, the most frequent being sequences like those of $\kappa$ chains of immunoglobulins and to a lesser extent ovoinhibitor from eggs. The analysis also revealed the presence of 'gaps' in the sequence. The most likely residues in these gaps were thought to be cysteine and, in fact, the homologies were based on this assumption. However, it is also possible that the gaps were glycosylated residues, the most common of which would have been serine and threonine in that order.

Amino acid composition of the lectin is given in Table 2. The lectin contained no detectable methion- ine, and was characterized by a relative abundance of hydrophobic amino acids, such as glycine, leucine, and valine.

\section{DISCUSSION}

The occurrence of lectins and haemagglutinins in the eggs of members of Pacific salmon Oncorhynchus spp. is well documented. These lectins have common D-galactosyl and L-rhamnosyl binding specificities (Voss et al. 1978, Ozaki et al. 1983, Kamiya et al. 1990). 
Table 2. Oncorhynchus kisutch. Total amino acid analysis of $24.5 \mathrm{kDa}$ coho salmon egg lectin. The molar ratio of each amino acid was determined from the compositional analysis, and the alanine content was adjusted for a lectun molecular mass approximating $24.5 \mathrm{kDa}$, the apparent molecular mass of the lectin subunit as determined by SDS-PAGE. nd: not determined

\begin{tabular}{|cc|}
\hline Amino acid residue & No. of residues per lectin subunit \\
\hline Asx & 17 \\
Glx & 20 \\
Ser & 17 \\
Gly & 32 \\
His & 3 \\
Arg & 8 \\
Thr & 18 \\
Ala & 20 \\
Pro & 9 \\
Tyr & 4 \\
Val & 23 \\
Cys & nd \\
Met & 0 \\
Ile & 23 \\
Leu & 26 \\
Phe & 6 \\
Trp & nd \\
Lys & 8 \\
Total & 234 \\
\hline
\end{tabular}

This study demonstrated the presence of a $24.5 \mathrm{kDa}$ D-galactosyl-specific lectin in the eggs of coho salmon as well as the presence of galactose-bearing lectin receptors on the surface of Aeromonas salmonicida cells. Similarly, lectins from the eggs of rainbow trout have been described as proteins in the form of monomers and noncovalently linked dimers (Krajhanzl \& Kocourek 1986), and an estimated molecular weight of $25 \mathrm{kDa}$, based on Sephadex G-200 molecular sieving, was reported for a lectin from the eggs of the powan Coregonus lavaretus maraena, a fish of the Salmonidae family (Krajhanzl et al. 1978).

Because of their specificity for certain sugar moieties, lectins are usually defined in terms of their ability to agglutinate erythrocytes in haemagglutination tests. Those reacting with the erythrocytes do so by virtue of the presence on the latter of carbohydrate configurations or antigenic determinants of the human blood group substances (Springer 1970). Indeed, many kinds of microorganisms, including bacteria, share surface structure components with vertebrate erythrocytes. In the present study, we used a modified adsorption test with SDS-PAGE, as opposed to the conventional haemagglutination test, to detect the protein in. adsorbed and unadsorbed samples of YE.

Among the sugars tested, D-galactose, L-rhamnose, and D-galactosamine markedly inhibited the lectin. This indicates that the lectin is a member of a group of similar anti-B-like lectins found in salmonid eggs, which share the sugar binding specificity (Uhlenbuck \& Prokop 1967, Anstee et al. 1973, Voak et al. 1974, Krajhanzl et al. 1978, Voss et al. 1978, Ozaki et al 1983, Bildfell et al. 1992) and insensitivity to 2-mercaptoethanol (Anstee et al. 1973, Ozaki et al 1983). These monosaccharide inhibitors are characterized by having a common structure at one of the carbon atoms in their pyranose ring. Those sugars, whose pyranose rings share the same configuration at $\mathrm{C}_{4}$ (i.e. hydroxyl group $-\mathrm{OH}$ ) also possess similar orientation with regard to the hydroxyl group. Some other sugars, such as Nacetyl D-galactosamine, have similar (compared to Lrhamnosyl type sugars) configuration at $\mathrm{C}_{4}$, yet they were unable to inhibit the lectin, perhaps because of their bulky size exemplified by the presence of an acetamido group $\left(\mathrm{CH}_{3}-\mathrm{CO}-\mathrm{NH}\right)$ at $\mathrm{C}_{2}$ of their pyranose ring. This indicates that the stereochemical configuration of the hydroxyl group alone may not predict inhibition activity for the sugar. The lack of inhibition by other sugars also tested could be attributed to differences in configuration of the pyranose ring as well as orientation of the vicinal hydroxyl group at $\mathrm{C}_{4}$.

The anomer specificity of the lectin purified from coho eggs was not determined in this study. However, previously published works indicated that lectins found in salmonid eggs are specific for $\alpha$ anomer (Voak et al. 1973, Ozaki et al. 1983). This was primarily based on inhibition of haemagglutination with the $\alpha$-galactosyl sugars melibiose and raffinose, but not with lactose (a $\beta$-galactosyl).

The adsorption of the lectin onto boiled cells indicated the relative resistance of the sugar-bearing residues of Aeromonas salmonicida cells to proteindenaturing agents and facilitates the use of fixed bacteria for studies of their interactions with the lectins. This Gram-negative bacterium is the etiological agent of septicemic furunculosis in salmonids. The bacterium possesses an additional cell envelope layer, the Alayer, located outside its outer membrane (Udey \& Fryer 1978. Trust et al. 1980, Evenberg \& Lugtenberg 1982) that has been implicated in adhesion, enhanced virulence, and autoagglutination (Udey \& Fryer 1978, Trust et al. 1980, Evenberg \& Lugtenberg 1982). It is a $49 \mathrm{kDa}$ protein (A protein) and covers most of the surface of virulent cells, although some lipopolysaccharide (LPS) may be exposed (Kay et al. 1981). In a different study (Yousif \& Albright unpubl.), cellular fractions from various $A$. salmonicida phenotypes reacted equally well with the lectin and showed that, besides the LPS core region, other cellular proteins and/or glycoproteins may also act as ligands for coho egg lectin.

The binding activity in the yolk was due to 1 lectin because: (1) D-galactose/L-rhamnose treatment of the YE-Aeromonas salmonicida complex yielded only 1 
protein band in SDS-PAGE, (2) sugar inhibition profiles of rhamnose- and galactose-eluted lectin were identical and (3) rhamnose- and galactose-eluted lectin had identical mobility in SDS-PAGE.

The source of the lectin present in coho salmon eggs was not investigated. However, cytochemical data indicated that sugar-binding proteins (lectins) in fish ova are present in the yolk vesicles of small oocytes and in cortical alveoli of full-grown oocytes and eggs (Nosek et al. 1983, Nosek 1984).

Although the existence of these egg proteins has been known for decades, few of them have been purified and biochemically characterized. In the present study, the amino acid composition and $\mathrm{N}$-terminal amino acid sequence of coho egg lectin were established. However. the BLAST computer search of N-terminal sequence databases did not reveal sequences homologous to those of the purified lectin. Of interest, however, was the weak homology that occurred with the variable region of $k$ light chains of mammalian immunoglobulins (Igs). These variable regions are known to form antigen-binding domains with their heavy chain counterparts. This similarity to an Ig-like structure may therefore classify the lectin as a member of an ancient superfamily of recognition molecules such as antibodies, T-cell receptors, major histocompatibility complex glycoproteins, and lymphocyte $F_{c}$ receptors. Studies using DNA techniques have shown that all of these molecules that mediate cell-cell recognition or antigen recognition in the immune system contain related structural elements (Iglike domains) suggesting that the genes that encode them have a common evolutionary history (Williams \& Barclay 1988)

In addition to $\mathrm{K}$ chains, there was weak homology to ovoinhibitor of eggs. Ovoinhibitor is a protein that belongs to a major group of proteinase inhibitors present in egg white. It is characterized by inhibiting serine proteinases such as trypsin, $\alpha$-chymotrypsin, subtilisin, and alkaline proteinases. Although the function of this protein is not known for certain, it is believed it may have a protective role against bacterial proteinases (Stevens 1991).

Acknowledgements. The authors thank Dr W. W. Kay, Department of Biochemistry and Microbiology, University of Victoria, British Columbia for the critical review of the manuscript. Thanks are also extended to the manager and staff of Capilano hatchery for the materials used in much of this research. This research was mutually supported by Natural Sciences and Engineering Research Council of Canada operating grants to L.J.A. and W. W. Kay.

\section{LITERATURE CITED}

Anstee, D. J., Holt, P. D. J., Pardoe, G. I. (1973). Agglutinins from fish ova defining blood groups B and P. Vox Sang. 25 : $347-360$
Austin, B., Embley, T M., Goodfellow, M. (1983). Selective isolation of Renibacterium salmoninarum. FEMS Microbiol. Lett. 17: 111-114

Bade, H., Stegemann, H. (1984). Rapid method of extraction of antibodies from hen egg yolk. J. immunol. Methods 72 : $421-426$

Bildfell, R. J., Frederick Markham, R. J., Johnson, G. R. (1992). Purification and partial characterization of a rainbow trout egg lectin. J. aquat. Anim. Health 4: 97-105

Bradford, M. M. (1976). A rapid and sensitive method for the quantitation of microgram quantities of protein. Analyt. Biochem. 72: 248-254

Daly, J. G., Stevenson, R. M. W. (1985). Charcoal agar, a new growth medium for the fish disease bacterium Renibacterium salmoninarum. Appl. environ. Microbiol. 50(4): $868-871$

Evelyn, T P. T (1977). An improved growth medium for the kidney disease bacterium and some notes on using the medium. Bull. Off. int. Epiz. 87: 511-513

Evenberg, D., Lugtenberg, B. (1982). Cell surface of the fish pathogenic bacterium Aeromonas salmonicida. I. Relationship between autoagglutination and the presence of a major cell envelope protein. Biochem. Biophys. Acta 684: 241-248

Johnstone, A., Thorpe, R. (1987). Polyacrylamide gel techniques. In: Johnstone, A., Thorpe, R. (eds.) Immunochemistry in practice, 2nd edn. Blackwell Scientific Publications. Oxford, p. 148-182

Kamiya, H., Muramoto, K., Goto, R. (1990). Properties of a lectin in chum salmon ova. Nippon Suisan Gakk. 56(7): $1139-1144$

Kay, W. W., Buckley, J. T., Ishiguro, E. E., Phipps, B. M., Monette, J. P. L., Trust, T J. (1981). Purification and disposition of a surface protein associated with virulence of Aeromonas salmonicida. J. Bacteriol. 147: 1077-1084

Krajhanzl, A., Horejsi, V., Kocourek, J. (1978). Studies on lectins XLI. Isolation and characterization of a blood group B specific lectin from the roe of the powan Coregonus lavaretus maraena. Biochem. Biophys. Acta 532: $209-214$

Krajhanzl, A., Kocourek, J. (1986). Fish cortical vesicle lectins - a new group of carbohydrate binding proteins: a review. In: Bog-Hansen, T C., Van Driessche, E. (eds.) Lectins: biology, biochemistry, clinical biochemistry, Vol. 5. Walter de Gruyter, Berlin, p. 257-275

Kudo, S. Inoue, M. (1986). A bactericidal effect of fertilization envelope extract from fish eggs. Zool. Sci. 3: 323-329

Kudo, S., Inoue, M. (1989). Bactericidal action of fertilization envelope extract from eggs of the fish Cyprinus carpio and Plecoglossus altivelis. J. exp. Zool. 250: 219-228

LeGendre, N., Matsudaira, P. (1988). Direct protein microsequencing from Immobilon ${ }^{\mathrm{TM}}$ - $\mathrm{P}$ transfer membrane. Biotechniques 6: 154-159

Nosek, J. (1984). Biogenesis of the cortical granules in fish oocyte. Histochem. J. 16: 435-437

Nosek, J., Krajhanzl, A., Kocourek, J. (1983). Studies on lectins LVII. lmmunofluorescence localization of lectins present in fish ovaries. Histochemistry 79: 131-139

Ozaki, H., Ohwaki, M., Fukada, T. (1983). Studies on lectins of amago Oncorhynchus rhodurus. I. Amago ova lectin. and its receptor on homologous macrophages. Dev comp. Immunol. 7: 77-87

Prokop, O., Uhlenbruck, G., Kohler, W. (1968). A new source of antibody-like substances having anti-blood group specificity. Vox Sang. 14: 321-333

Sharon, N., Lis, H. (1989). Lectins. Chapman and Hall, London, p. 21-114 
Springer, G. F. (1970). Role of human cell surface structures in interactions between man and microbes. Naturwissenschaften $57 \cdot 162-171$

Stevens, L. (1991). Egg white proteins (mini-review). Comp. Biochem. Physiol. 100B(1): 1-9

Trust, T J., Howard, P. S., Chamberlain, J. P., Ishiguro, E. E., Buckley, J. T (1980). Additional surface protein in autoaggregating strains of atypical Aeromonas salmonicida. FEMS Lett. 9: 35-38

Udey, L. R., Fryer, J. L. (1978). Immunization of fish with bacterins of Aeromonas salmonicida. Mar Fish. Rev. 40: $12-17$

Uhlenbuck, G., Prokop, O. (1967). An incomplete antibody for

Editorial responsibility: Managing Editor red cells in salmon caviar. Vox Sang. 12: 465-466

Voak, D., Todd, G. M., Pardoe, G. I. (1973). The $\alpha$-galactose specificity of anti- $\mathrm{P}^{k}$ Vox Sang. 25: 263-270

Voak, D., Todd, G. M., Pardoe, G. I. (1974). A study of the serological behavior and nature of the anti-B/P/Pk activity of Salmonidae roe protectins. Vox Sang. 26: 176-188

Voss, E. W., Fryer, J. L., Banowetz, G. M. (1978). Isolation, purification, and partial characterization of a lectin from chinook salmon ova. Arch. Biochem. Biophys. 186(1): $25-34$

Williams, A. F., Barclay, A. N. (1988). The immunoglobulin superfamily - domains for cell surface recognition. A. Rev. Immunol. 6: 381-402

Manuscript first received: December 4, 1993

Revised version accepted: August 25, 1994 